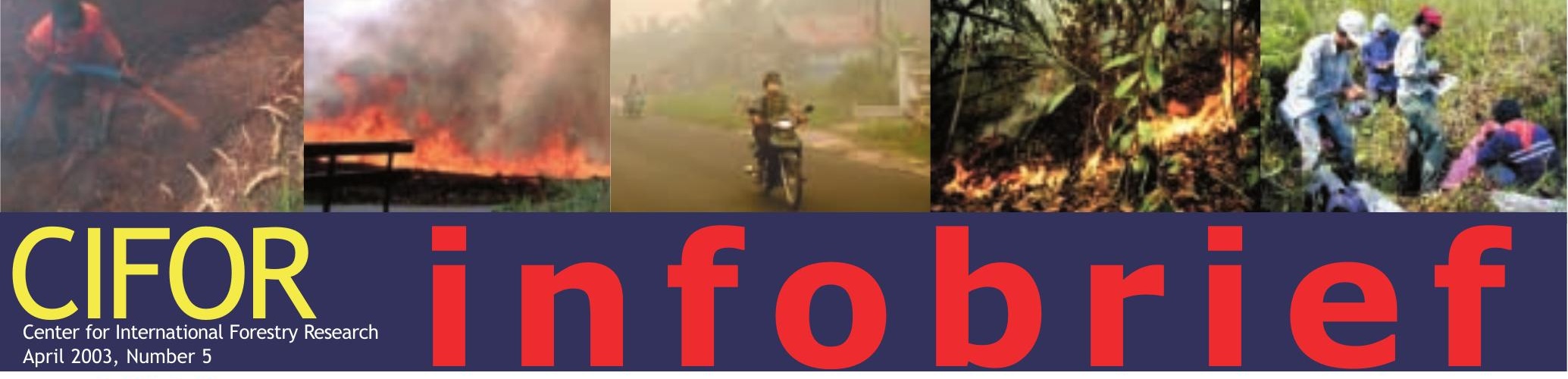

CIFOR infobrief provides concise, accurate, peer-reviewed information on current topics in forest research

\title{
Fires in Indonesia: Causes, costs and policy implications
}

\section{Key points}

- When fire is used to clear forest allocated to other land uses, such as plantations, fire is not the underlying cause of forest loss. In this case, the land allocation process needs to be addressed to reduce deforestation.

- There is no single 'fire problem'. Rather, there are a range of fire-related problems that require their own appropriate policy response, such as smoke haze pollution, forest degradation and deforestation.

- Large-scale land clearing for plantations and small-scale livelihood activities are both major causes of the peat-land fires that produce most of Indonesia's smoke haze pollution and carbon emissions.

- Legislation governing fire use should be revised so that it a) bans those fires that cause significant smoke haze effects, such as peat-land fires, and b) regulates fire-uses that cause unwanted local effects resulting from smoke.

Fire is the main method used to clear land for agriculture in East Kalimantan, Indonesia (photo by Carol J.P. Colfer)
Fires threaten sustainable development because of their direct effects on ecosystems, their contribution to carbon emissions and their impact on biodiversity. Fires have become an environmental and economic issue, especially since 25 million hectares of land worldwide were burnt after the 1997-98 El Niño Southern Oscillation (ENSO) event. During that period, Indonesia had the most severe fires in the world, and experienced similar problems during the ENSO year of 2002. New research has revised the extent and location of fires in Indonesia in 1997-98, from 9.7 million hectares to 11.7 million hectares affected (Table 1 ).

Table 1. Estimates of area affected by (1997/98)

\begin{tabular}{lr} 
Vegetation type & Total (ha) \\
\hline Montane forest & 313194 \\
Lowland forest & 3598880 \\
Peat and swamp forest & 2124000 \\
Dry scrub and grass & 763000 \\
Timber plantation & 955988 \\
Estate crops & 46509 \\
Agriculture & 3496808 \\
& \\
Total & 11698379
\end{tabular}

\section{Causes}

In ENSO years, smoke haze pollution is caused by land clearing fires for oil palm and timber plantations in the peat lands of Jambi, Riau, South Sumatra, West Kalimantan and Central Kalimantan provinces, and by fires for livelihood activities-such as rice cultivation, fishing, and logging-in the wetlands of South Sumatra, West Kalimantan and Central Kalimantan. In non-ENSO years, land clearing for plantations on peat lands appears to be the main source of smoke haze pollution.

In 1997-98, East Kalimantan had the most extensive area of fire-affected lowland forest, about $60 \%$ of the total. 
It was also the area most severely affected by the ENSO related drought. The causes of fire ignition are not yet fully understood, but ignition zones were distributed almost proportionally to land use allocation. This indicates all land uses were affected to a similar extent and that escaped fires were predominantly related to a range of commercial and livelihood activities. The contribution of the various activities needs to be further explored.

While forest fires in 1997 were much more extensive than in non-ENSO years, indicating there may have been escaped fires, the fires in Sumatra, Sulawesi, West Papua, and West and Central Kalimantan appear to have occurred in land clearing areas, and in South Sumatra fires affected mainly degraded forest and shrub. To better calculate economic losses and develop remedial policies, it is crucial to distinguish between the unplanned loss of forest from fires and the loss of forest due to fire-use in planned forest clearance or due to fires that escape but remain within allocated land clearing areas.

\section{Costs}

The economic impacts of the 1997-98 fires have also been revised, showing that forest degradation and deforestation cost Indonesia between US\$1.62 and 2.7 billion (Table 2). Smoke haze pollution cost Indonesia, Singapore and Malaysia at least US\$674-799 million, and probably higher if the economic impacts on Indonesian business activities are estimated. On top of these amounts are the global costs associated with carbon emissions, which may amount to as much as US\$2.8 billion.

Table 2. Estimated economic costs of deforestation fires

\begin{tabular}{lc} 
Cost item & Cost (US\$million) \\
\hline Timber & $1056-1614$ \\
Lost growth of timber & $197-316$ \\
Timber plantation & 91 \\
NTFPs & $0-8$ \\
Plantation crops & 319 \\
Indirect forest benefits & \\
Flood protection & $0-37$ \\
Erosion and silting & $0-122$ \\
Biodiversity & $0-181$ \\
Firefighting & 12 \\
Transmigration, property & 1 \\
Total & $1675-2700$
\end{tabular}

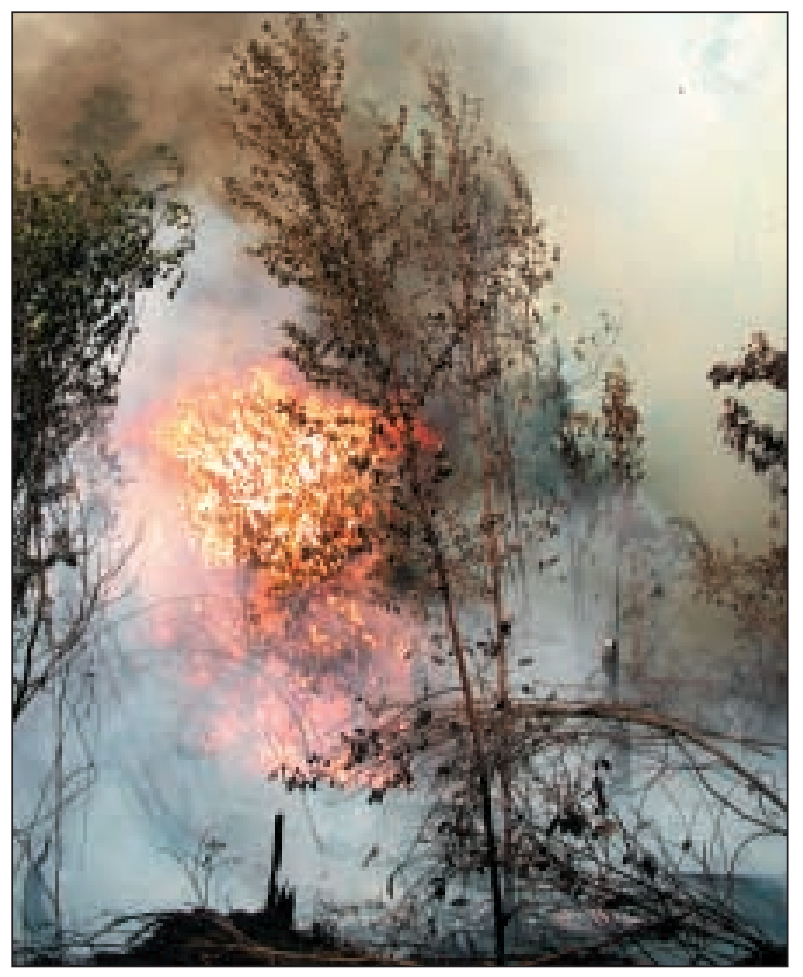

Despite several studies on the subject, progress towards resolving Indonesia's fire problems has been hampered by confusion over the nature of the policy problems, lack of understanding of the economic impacts, lack of clarity over the causes of fires and uncertainty about the appropriate institutional and economic responses.

\section{Policy implications}

Fire-related policy problems include smoke haze pollution, forest degradation and deforestation, and the negative impacts of fire on the rural sector. However, their true nature is poorly understood and different problems occur in different parts of the country with differing levels and types of impact.

A continued emphasis on emergency response will not prevent large and damaging fires. The Government of Indonesia, industry and non-government organizations need to form an alliance genuinely committed to addressing this national and international environmental, economic and social predicament.

Preventative measures need to be targeted at the specific policy problem, take into account relevant costs to assess the benefits of the proposed policy, and 
Large-scale land clearing for plantations and small-scale livelihood activities are both major causes of fires (photo by Mark Van Nieuwstadt)

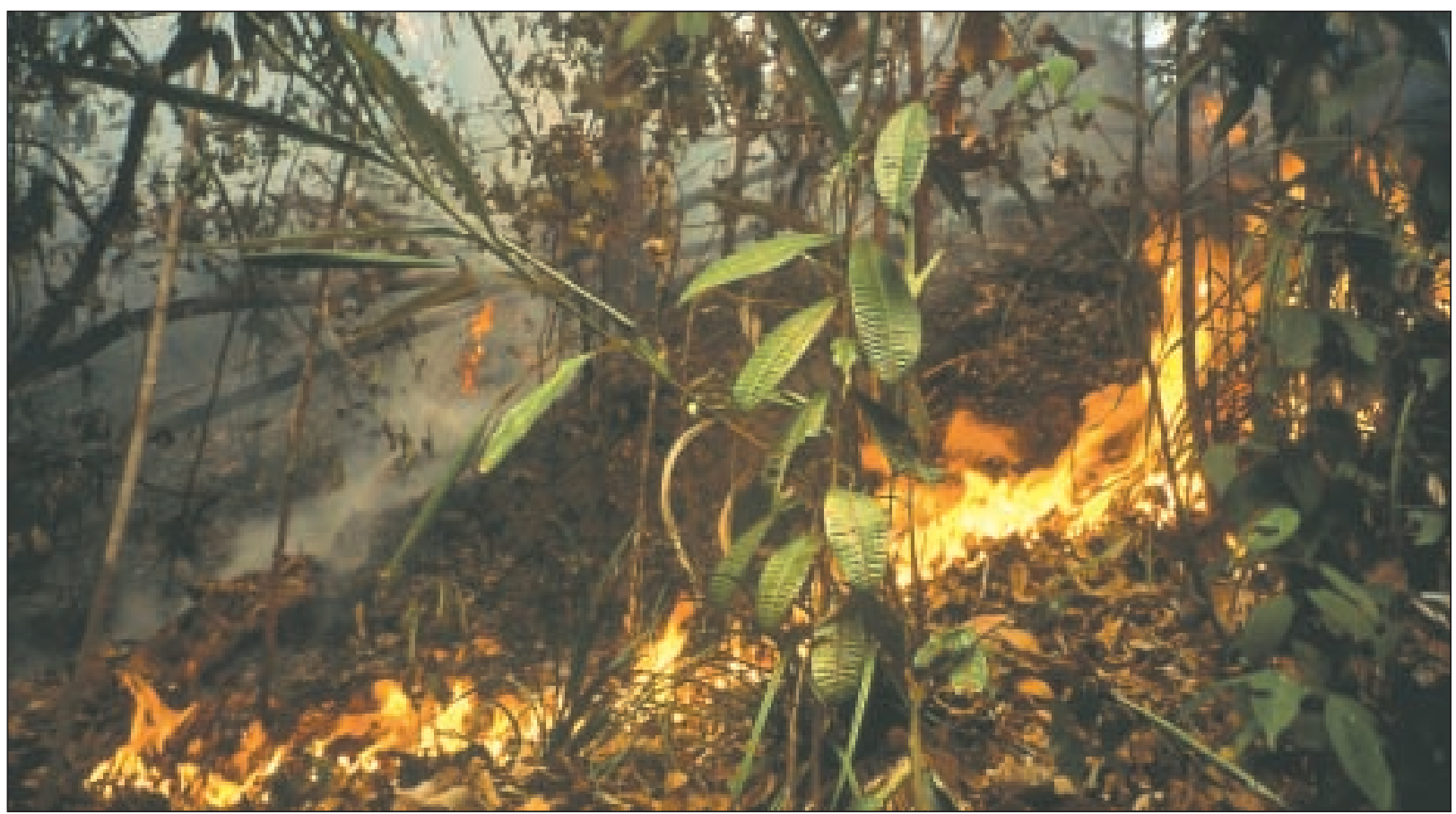

address the specific causes of the problems. Policy initiatives aimed at addressing fire-related problems need to take into account a number of factors:

- The costs and the benefits of the use of fire, as well as their distribution

- The different causes and impacts of fire, so they can be accounted for in the economic assessment of new policies

- The incentives for concession holders to invest in fire prevention and suppression

- The full impact of fires on forest functions needs to better addressed so that the full range of potential losses from smoke haze pollution can be estimated

- Economic as well as environmental indicators need to be taken into account in the development of policies aimed at minimizing the impacts of fires and smoke haze.

\section{Fires, degradation, deforestation and land use allocation}

In most cases it is the allocation of forest to alternative land uses, such as oil palm plantations, and the factors underlying that decision, that leads to deforestation, rather than the fires used to clear the allocated land.
To support improved resource management, research is needed to assess the areas of low access forest, primary forest and secondary forest areas that may present an increased fire risk.

\section{Fires and smoke haze pollution}

There is still a significant lack of knowledge about the human activities contributing to smoke haze pollution that is at a level appropriate for district and provincial policy making. Further analysis is needed to fill this knowledge gap and to develop appropriate policy responses.

In non-ENSO years plantation activities appear to be the major contributing factor, but the increasing role of smallholder activities, especially in West and Central Kalimantan, needs to be ascertained. Reducing and managing land-clearing fires in peat lands would probably eliminate much of the smoke haze problem in non-ENSO years. However, the costs, benefits and distributional aspects of policy initiatives aimed at reducing the impacts of these fires need to be assessed.

In ENSO years, degraded peat lands may be the most significant risk factor for the generation of smoke haze. Their management and eventually their 
regeneration and or restoration may be required to avoid significant events of air pollution.

\section{Fires and legislation}

An analysis of the appropriateness of the legislation regulating the development of peat lands, including their social, economic and environmental implications, is needed.

If the fire itself is not causing a policy problem, such as deforestation, there is no reason for the current legislation that outlaws all use of fire in plantations. The legislation should be revised so that it bans fires that have significant smoke haze effects, such as those on peat land. It should also regulate the use of fire in situations and locations that may have unwanted local effects resulting from smoke, such as on health or transport. Where fires may cause unwanted deforestation, the appropriate authorities should be given the power to regulate and, if required, ban fire use in particular periods, such as during ENSO events.

To make laws effective, clear punitive examples are needed to force companies to change their use of fire. This means that companies using fire unlawfully need to be prosecuted. If found guilty, the penalties imposed on the companies must be large enough to act as a deterrent. However, when livelihood activities are involved in a fire or smoke haze problem, only community-based initiatives that address livelihood needs, backed by legislative means, have any likelihood of succeeding.

\section{Carbon sinks}

Given the contribution of peat fires to carbon emissions, there is a need to consider whether conservation of peat lands should be included in the second commitment period of the Kyoto Protocol.

Provinces affected by fires and distribution of smoke haze pollution in 1997/98
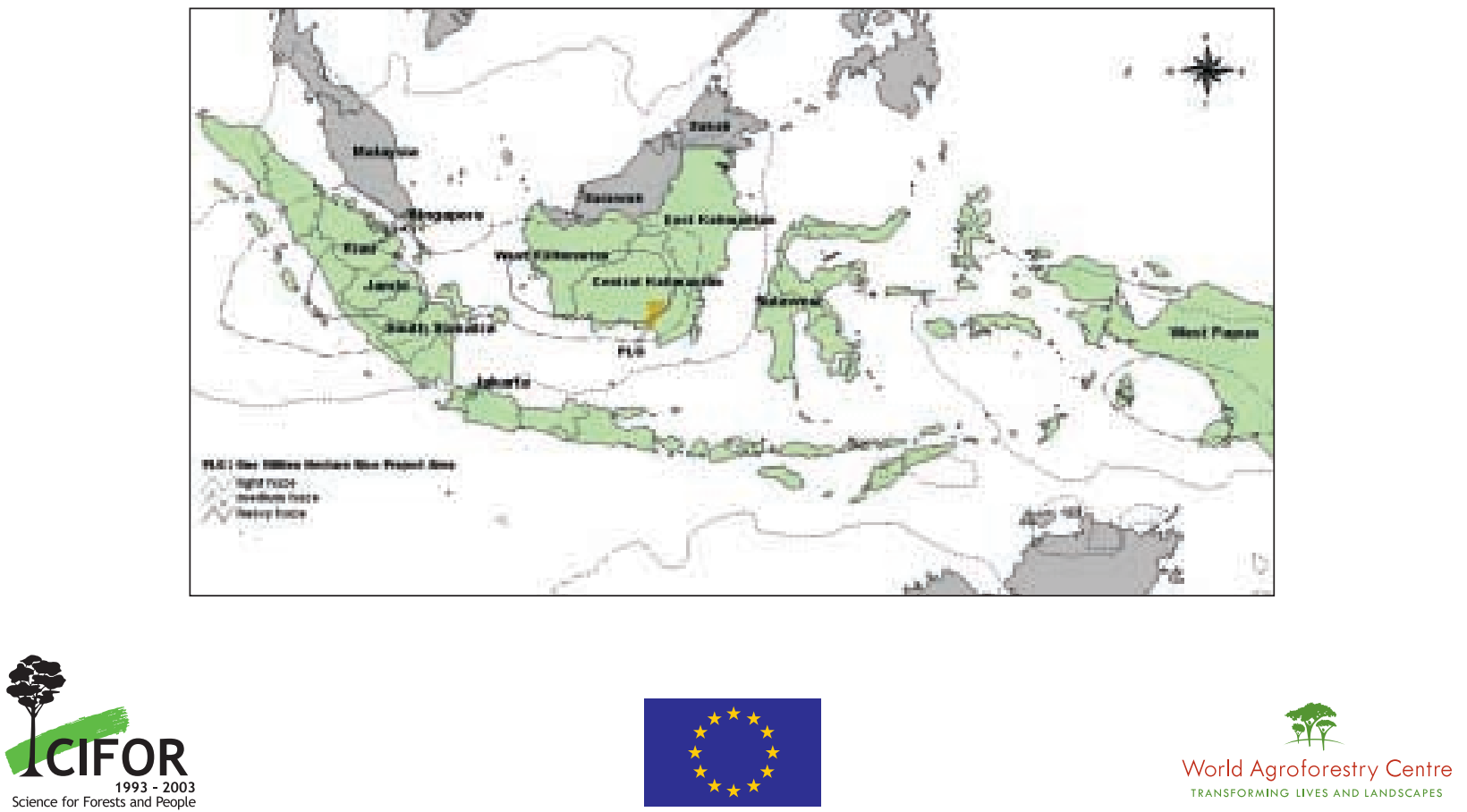

This infobrief is based on CIFOR Occasional Paper "Fires in Indonesia: causes, costs and policy implications" (2003) by Luca Tacconi, Center for International Forestry Research. Research for the infobrief and the Occasional Paper was carried out under 'The Underlying Causes and Impacts of Fires in Indonesia' project with support from the European Commission SCR Common Service for External Relations Budget Line (B7-6201), and in close cooperation with the World Agroforestry Centre.
Center for International Forestry Research office: Jalan CIFOR, Situ Gede, Sindang Barang, Bogor Barat 16680, Indonesia.

mailing: P.O. Box. 6596 JKPWB, Jakarta 10065, Indonesia Tel: +62(251) 622622 Fax: +62(251) 622100

E-mail: cifor@cgiar.org Website: www.cifor.cgiar.org

Cover photos: Yayat Ruchiat, Rona Dennis and Mark Van Niewstadt

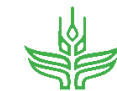

